\title{
Instantiation of Complexity of Students and Teachers' Learnings in an EFL Classroom
}

\section{Instanciação da complexidade da aprendizagem de alunos e professores na sala de aula de inglês como língua estrangeira}

Nayibe Rosado*

Instituto de Idiomas, Universidad del Norte (Uninorte)

Barranquilla - Colombia

\begin{abstract}
This article reports on some of the results of a study whose objective was to interpret students' and teachers' learning as it emerged out of the interactions generated in and beyond the context of their EFL class in a state school in Barranquilla, Colombia. In this study I use principles of complex systems (MORIN, 1994) to make sense of the learning systems of students and teachers in an EFL class in Barranquilla, Colombia. The data for this ethnographic case-study include classroom observations, interviews, learning journals and documents (students' notebooks, worksheets, quizzes, and syllabus). A qualitative software program (Atlas.ti 6.0) was used to process data. Results from this study contribute to understand learning as a complex system by approaching students' learning from a complex perspective recursively connected to teachers' learning.

KEYWORDS: students' learning; teachers' learning; complexity; principles of complex systems; ethnographic case study; EFL.

RESUMO: Este artigo relata alguns dos resultados de um estudo cujo objetivo foi interpretar a aprendizagem de alunos e professores que emergiram das interaçôes geradas no e além do contexto de suas salas de aula inglês como língua estrangeira em uma escola estadual em Barranquilla, Colômbia. Neste estudo, uso princípios dos sistemas complexos (MORIN, 1994) para compreender os sistemas de aprendizagem de alunos e de professores. Os dados para este estudo de caso etnográfico incluem observaçôes de sala de aula, entrevistas, diários de aprendizagem e documentos (cadernos dos alunos, folhas de exercícios, quizzes, e o currículo). Um software para análise qualitativa (Atlas.ti 6.0) foi usado para a análise dos
\end{abstract}

*nrosado@uninorte.edu.co 
dados. Os resultados deste estudo contribuem para compreender a aprendizagem como um sistema complexo ao abordar a aprendizagem dos alunos por meio de uma perspectiva complexa, recursivamente associada à aprendizagem dos professores.

PALAVRAS-CHAVE: aprendizagem de alunos; aprendizagem de professores; complexidade; princípios dos sistemas complexos; estudo de caso etnográfico; ensino de inglês como língua estrangeira.

"Two roads diverged in a wood, and I - I took the one less travelled by, and that has made all the difference".

Robert Frost (1874-1963), Mountain Interval, 1920.

As suggested in the introductory quote, in this paper, I take the less traveled road and used a complexity perspective to research and understand students' and teachers' learnings. I have tried to honor the complexity of the learning phenomena by drawing on principles of complex systems: the dialogical principle, the recursive principle, the holographic principle, the selfeco-organization principle, the emergence principle and the fuzziness principle (MORIN, 1994) to make sense of the learning systems of students and teachers in an EFL class in Barranquilla, Colombia.

\section{Teachers' and students' learning: complex systems}

Teachers' and students' learning are complex systems and as such they display the characteristic features of complex systems: dynamic, open, emergent, and non-linear and are governed by some principles associated with complex systems: the dialogical principle, the recursive, the holographic, the self-eco-organizing, the emergence and the fuzziness principle (MORIN, 1994).

Teachers' and students' learning are "nested, co-entangled and networked systems" (DAVIS; SUMARA, 2012, p. 30) existing within and beyond the classroom. In the classroom (another complex system), as lessons unfold through moves (SWALES, 1990) and registers, (CHRISTIE, 2002), one can perceive the dynamism, the openness, emergence, and the non-linearity of the systems; the continuities and the discontinuities, which are characteristic of complex phenomena, instantiated in different ways. Outside the classroom, the ways the systems function unveil through the narratives of the learners (teachers and students) emerging in their journals or in the interviews.

Classes follow certain sequences that when looked at as a whole give information about the linearity (MORIN; LE MOIGNE, 1999) which is an 
important perspective, an important layer of complex systems: greeting, opening the class, developing the class, closing the class. The sequence that is used by teachers, for example, presentation, practice, production, and the students' following of the sequence also contributes to the perception of linearity, to the perception of a sense of equilibrium, a sense of established order (MENEZES, 2009). However, within this apparent order, linearity and equilibrium, there are instances of chaos and discontinuities which are also part of complex systems.

This report will highlight the principles governing these complex systems. The principles of complex systems are connected among themselves as part of the complex reality they refer to, so for clarity purposes, I highlight certain principles in some of the data, and de-emphasize others, but this should not be taken as if there were not other principles co-occurring there, too.

\section{The case study ${ }^{1}$}

The research was developed using an ethnographic case study that allowed me as a researcher to gain an in-depth understanding of a situation in these EFL classes and the meaning for those involved (for teachers, for learners and for me as a researcher). It also provided me with an opportunity to experience complexity, since a case study instantiates complexity and some of its principles: the dialogical principle, the recursive principle and the holographic principle.

The purpose of the case study was to interpret students' and teachers' learning as it emerged out of the interactions generated by their learning systems in and beyond the context of their EFL class in a state school in Barranquilla, Colombia.

\section{Participants}

Primary participants in this case are two groups of students and their teachers. One group is made up by 35, highly motivated, 11 to 12 year-old learners from the $6^{\text {th }}$ grade class, coming from neighboring primary schools and with very little experience in English learning. They have a basic level of

\footnotetext{
${ }^{1}$ This article derives from chapter 5 of my doctoral thesis "a fractal of students' and teachers' learning systems in Colombian EFL classrooms" completed in the Doctor in Education Program in Universidad del Atlántico in Barranquilla, Colombia.
} 
English or an $\mathrm{A}^{2}$ level, according to the labels adopted in Colombia from the Common European Framework of Reference (COUNCIL OF EUROPE, 2001). The second group is also a highly motivated group of 29,15 to 17 yearold, pre-intermediate or B1 level learners from the $10^{\text {th }}$ grade class. They have been in the school since $6^{\text {th }}$ grade and some even from primary. They live close to the school.

Participant teachers for this case study are two female EFL teachers. The $6^{\text {th }}$ grade teacher is in her mid-thirties and holds a BA in education with emphasis in foreign language teaching from the state university in town. She has been a teacher for about 10 years. She has been working in this state school since 2006. Her language level is that of a proficient user of the language (B1-B2). ${ }^{3}$ She participated in a training course about integration of new technologies into teaching and in a course to become a mentor for other teachers.

The $10^{\text {th }}$ grade teacher is in her early forties and holds a BA in education with emphasis in foreign language teaching, she has been a teacher for more than fifteen years and has worked in various private schools and language institutes in the city. She has completed a Postgraduate course in TEFL and is currently completing her Masters degree in TEFL. Her language level is that of a proficient user of the language or $\mathrm{C} 1$. She has been the coordinator of the EFL program at school. She took an International in-service teacher certification program and was a tutor for a Teacher Development Course for other teachers in town.

Both teachers follow the EFL syllabus that was designed by the EFL coordination of the school and they both use an EFL text book (New Generation 6 and 10 respectively, published by Greenwich ELT, a Colombian publishing house). The blurb states it is a communicative oriented book. The teachers also design worksheets for students to use in and out of the class. They are both familiarized with New Communication Technologies (NCT) and regularly use the computer laboratory the school has to support EFL learning.

${ }^{2}$ Colombian government has adapted the Common European Framework of Reference (CEFR) as the international benchmark for language proficiency levels. In this framework A1 is the first level followed by A2, B1, B2, C1 and C2.

${ }^{3}$ Levels corresponding to the ones proposed by the common European Framework of reference for language learning, teaching and assessment. (COUNCIL OF EUROPE, 2001) 
The third participant is the researcher of this study (myself) as a nonnative EFL teacher, an observer and a researcher, a main instrument and source of interpretation in this study. My role as a participant-observer provided unusual opportunities to collect data from an emic, insider's perspective (YIN, 2003 , p. 94), to observe and record the events in the class aware that my experience as an EFL, non-native (BRAINE, 2010) teacher and teacher educator filtered the way I perceived and reacted to the class ecology. This represented both a strength and a weakness for this study because I could interpret the realities of the EFL class from this perspective, but I brought those biases to this study, too. The EFL class is a complex system and as stated by Larsen-Freeman and Cameron (2008a, p. 207), "A complex system is dependent on its initial conditions, and these conditions include the researcher". So by recognizing my own role and my biases, I strived to increase my awareness and the validity and reliability of the subsequent analysis.

\section{Classroom observation}

Observation allowed me to capture the cycle of activities that make up a complete instructional unit ${ }^{4}$ spanning an extended period of time: variety of texts, tasks, and interactions. The choice of participants from two levels $\left(6^{\text {th }}\right.$ and $\left.10^{\text {th }}\right)$ allowed me to have data about the configuration of their learning systems at various stages of development.

The $6^{\text {th }}$ grade class met twice a week: Wednesdays from 4:30 to 6:30 P.M and Fridays from 12:30 to 1:30 P.M. The $10^{\text {th }}$ grade class met three times: Tuesdays from 12:30 to 2:30, Thursdays from 3:45 to 4:30 and Fridays from 1:30 to 2:30. I did some preliminary visits prior to the actual observation, in their own space or "setting" (DENZIN; LINCOLN, 2008, p. 131) to create an atmosphere of trust and acceptance in the groups. I started audio taping the lessons in the preliminary visits then I audio and videotaped classes (FASSE; KOLODNER, 2000) and took field notes on events that were not visible, explicit or easily captured in audio or video.

After observations, I made audio or written entries in journal on main events or special remarks on the class. Transcription of the classes' audio recording was done as soon as possible after the class to minimize the risk of forgetting important details of the class (MARSHALL; ROSSMAN, 2006,

\footnotetext{
${ }^{4}$ An academic term of instruction lasts two months more or less and should provide 24 hrs of interaction per group.
} 
p. 110). I used a simple observational protocol with demographic information about the observation (time, place, date) and two columns; in one column, I described what teachers and students did during the class and on the other column, my reflective notes.

\section{Interviews}

I conducted different types of interviews: informal before and after classroom observation, semi-structured interviews and video generated ones. All interviews were open ended in nature aiming at exploring the facts, opinions and insights participants could have about the occurrences during their EFL class (YIN, 2003, p. 90). I used a simple interview protocol with demographic information (time, date and participants in the interview), the questions asked, some space for recording interviewees' answers and some space for writing reflective notes. All interviews were audio-recorded and transcribed for later analysis. Teachers were interviewed before and after classes and once or twice during the process and at the end of the observation process. Students were interviewed during the observation process as many times as possible in-class trying not to interfere with the normal flow of the classroom events, sometimes during class activities to elicit their insights about their learning process and at the end of the observation process as well.

\section{Documentary data}

As learning is understood in this study as a multifaceted, multilayered endeavor, collecting data from different sources could help reconstruct the angles and sides of participants' learning systems. Learning journals, students' notebooks, worksheets and quizzes, syllabi, lesson plans, official grade reports are examples of the type of documents that could help this purpose. Learning journal entries provided data into what teachers and students noticed and noted down as happenings from the classroom. Notebooks provided some data to compare to classroom observation data about the type of activities students developed in class and as homework, the kind of information students noted down. Completed worksheets, quizzes provided information into the type of learning tasks and assessment activities teachers designed. In short, documents collected "corroborate and augment evidence from other sources" (YIN, 2003, p. 87).

A qualitative research software program was used in this study as a tool to aid in the data analysis process. I used a qualitative data analysis computer program called Atlas.ti (versions 5.0 to 6.2) developed by Thomas Muhr. Atlas.ti serves as 
a powerful utility for qualitative analysis, particularly of larger bodies of textual, graphical, audio, and video data. I used the software for the textual-level research activities that "include segmenting documents into quotations, adding comments to respective passages (note making/annotating), and coding selected document passages, secondary text materials, annotations, and memos to facilitate their retrieval" (MUHR; FRIESE, 2004, p. 25).

When retrieved from the software, the data carry some information that makes it easier for the reader to locate the selected data in the primary documents saved in the document manager in the software. For example P1 $6 G$ Class. (4-7) refers to primary document 1 (P1) from the $6^{\text {th }}$ grade case, $(6 \mathrm{G})$ originated from classroom observation (Class) which starts in line 4 and ends in line 7.

\section{A word on emergent categories and on the emic perspective}

I must recognize the insider's perspective and the way my own knowledge, beliefs, and awareness, as a teacher, teacher educator and researcher have permeated the emerging categories (DEVEREUX, 1967) presented here. So there is this recursive and dialogical connection between the participants, the collected data and the researcher that feedback upon each other and the resulting understanding and abstraction emerges as something new, supported by what already exists both in my landscape of experience and in the experience of participants and in the concreteness of the data collected. For example: the distinction between components of teachers' learning systems sometimes may be sharp and clear and some others may be blurry and entangled. I find this normal since the divisions are more for the academic purpose of separating wholes into their constitutive parts. As Morin puts it "a system requires a subject who isolates it, cuts it up, qualifies it, and hierarchizes it, based on her / his selective interests and the cultural and social contexts of scientific knowledge" (MORIN, 1977/1992). This is an ingrained habit in our way of thinking and researching but, as has been recognized by researchers in the field, most categories (that represent reality somehow) co-exist in dialogical tension and even in paradoxical states, a fact that will become evident as the results are presented.

\section{Ethical considerations}

An ethnographic case study invades the life of the participants and implies a great level of sharing of information that could be sensitive; for a 
teacher, for example, noticing areas for development, language difficulties when delivering the class and talking about it in interviews, is not easy (LOCKE; SPIRDUSO; SILVERMAN, 2000). In order to respect the rights, needs, values and desires of the participants the following safeguards were employed: a written permission was obtained from the principal of the school who was informed of the project, the aims, the procedures; as well as the participating teachers and students. Video and audio-recordings were shared with teachers and students, transcriptions and interpretations were shared with teachers as well as reports which will also be made available to the school's principal. Participants' anonymity was kept at all times, so names of teachers and students will be changed when the data are reported.

\section{Results}

For organizational purposes and coherent with the complexity epistemology supporting this research, the results are presented in the following manner; data from both cases are presented using complexity principles as the organizing headings, with the purpose of looking at, connecting and presenting data from complexified perspectives.

\section{Dialogicity and recursion in students' and teachers' learning systems}

The dialogical principle refers to the fact that two items of study always exist in a dynamic tension like the two sides of a coin; the recursive principle means that dialogical processes are circular, and feed back upon themselves. In the cases of the two classes participating in this study I find examples of these two principles in action.

Teaching and learning interact dialogically and recursively in a complex manner (DAVIS; SUMARA, 2012; FERYOK, 2010; JÖRG, 2009). The common perception of a good class, for example, is connected to the existence of the two sides of the coin: teacher's actions which dialogically coexist with students' actions and which interact through the lesson harmoniously. Traditionally, the development of a class is considered successful when this relationship is established, when the teacher's and students' feedback upon each other. Dialogicity and recursion are instantiated in different moments of the class; in opening exchanges, such as in greetings, for example and in exchanges in other developmental moments of the class. Dialogicity and recursion are 
realized in the nested use of regulative and instructional discourses emerging in classroom interaction as well as in the tension of the instantiation of activities originating from learning theories commonly perceived (by researchers, teachers and teacher educators) as opposing such as behaviorist, cognitivist, interactionist, to mention a few. In this section, there are some examples to illustrate this instantiation as I perceive it.

Extract 1 displays a rich bilingual dialogical and recursive space in which a pair of students from $10^{\text {th }}$ grade is completing what one could label as a behaviorist-oriented activity. In doing so, they help each other to make sense of language structures, they code-switch in order to further clarify a point, they give and receive feedback, they negotiate meaning with a more competent interlocutor.

\section{(1)}

1. S15: They have talked. Seria Yes, yes, they have. Y aqui es no, they haven't.

2. S16: ¿O sea que aqui va haven't?

3. S15: Aja.

4. S16: ¿No, I haven't?

5. S15: Ya, eso es todo.

6. S16: Cuando es el haven't, have y cuando es el had, hadn't. ¿Cuándo se coloca had?

7. S15: Es hady hadn't.

8. S16: Hadn't.

9. S15: Ya.

P $110^{\text {th }}$ G Class (957-1002)

The exchange in extract 2 finishes and evolves into 3, into what is called a zone of interactional transition (MARKEE, 2004) where learners and teacher move from talk amongst students during group work to teacher-student exchanges. The teacher intervenes regulatively (using regulative register) because she notices some difficulties and mistakes during the practice stage. She may be aiming at limiting perturbations and teaching about language in order to regain control of a learning activity that may seem off-track. In 3, the teacher initiates with the purpose of regaining the class attention, some students continue with the activity, and then teacher-student exchanges start. The teacher responds to the learner by inserting a counter question (turns 12, 15, 21 of the extract) thus regaining the initiation slot and repositioning the student as the one whose answer is a candidate for evaluation or feedback and 
in this way repositioning herself as the one who can provide that support. The exchange in extract 6 unfolds in a very dialogical manner showing the tension between hierarchy and power in the dynamics of teacher-students exchanges.

(3)

1. T: Listen, please. Now listen, everybody.

2. S1: I haven't do. (the student is still doing the practice activity)

3. T: ¿Por qué?, no. Ahi voy a explicar, muchas tienen errores en eso.

4. S2: Viste, yo te estaba diciendo( talking to S1)

5. S1: No es haven't do, entonces sería don't you.

6. T: Aja, ¿por qué don'tyou?

7. S1: Porque have es en... presente.

8. T: A ver, ! pay attention!

9. S1: Porque está en presente simple.

10. T: Está en presente simple. Ahi voy a explicar porque muchas de ustedes tienen errores en eso.

11. S2. Viste, yo te estaba diciendo (to S1).

12. T. Aja y ¿por quéseria don't you?, porque muchas que me llamaron, no sabian.

13. S1. Si, está en presente simple.

P $110^{\text {th }}$ G Class $(957-1002)$

\section{Dialogicity and recursion in teachers' learning systems}

Teachers' learning at its core is related to teachers as learners of teaching as stated by Johnson (2009). In extract 4, the $10^{\text {th }}$ grade teacher reflects about an activity she developed in class. She is using this external, observable activity that she and her students enacted and is assessing students' responses to it, noticing what happened; looking back in retrospect and somehow contrasting what she had expected students to achieve with what they actually did. She is engaged in dialogical reflection with reality as perceived in retrospection. In extract 5 , she sets an action recursively based on her reflection of a concrete practical experience from the class. I see the networked and dialogical presence of various layers of her learning or cognitions: her knowledge of students, her knowledge of the curriculum and her instructional knowledge. 
(4)

Besides, another objective of this task was to evaluate students' vocabulary, grammar and comprehension. During the activity performance, I could notice some students used L1 when I consider it was easy for them to use L2, according to what they have studied so far. Others showed that it was the first time they were interacting using L2. Some others showed lack of comprehension regarding questions about age, daily routines, etc. After this activity, I asked them some questions where they should have used the tensespresent-past, future with will and going to, and the present perfect, but they showed confusion on using them.

P $410^{\text {th }}$ GT Journal (5)

In short, I could observe they need to improve on their communicative skills regarding personal information that involves basic topics like talking about routines, age, favorite stuff... From this, I decided that the next topic was to review all the tenses, starting by simple present.

P $410^{\text {th }}$ GT Journal (7)

As documented by research in the field 5 the learning system of teachers is complex, including different time frames that comprise, for example, teachers' present and past experiences as learners and as learners of teaching (LORTIE, 1975). Both teachers in this study refer to this time frame layer of their cognition. They seem to dialogically recur to their previous experience to filter some of their present decisions or actions. So dialogical relations among layers of teachers' learning or cognitions are not only circumscribed to real time, synchronic connections (as connections that would happen in the course of classroom interaction), but they also seem to have an asynchronic, delayed effect that has been termed apprenticeship of observation (LORTIE, 1975). In extract 6, the $6^{\text {th }}$ grade teacher brings back her learning-to-be-a-teacher experience as a reference for what she would like her current teaching to be. In extract 7 , the $10^{\text {th }}$ grade teacher bases some of her instructional decisions, what to teach, and how to teach it, on her own language learning experience both past as a learner and recent as a language user in the role of a test taker.

\footnotetext{
${ }^{5}$ See Feryok, 2010 for a summary.
} 
(6)

As an English teacher, I have always been dreaming to teach English naturally and humorously as my teachers at the university did.

P 2 6GT Journal (77)

(7)

¿Y de pronto de dónde yo tomo eso? Yo aprendi así. Yo aprendi así y quizás una de mis fortalezas en los exámenes internacionales, por lo menos en TOEFL, yo no me equivocaba en ninguna porque yo adquirí estrategias de lectura, es decir, yo buscaba... Veo la respuesta... Exactamente... ¿Por qué no es esta? Inmediatamente deducía a pesar de que no entendia. Entonces, ¿cómo trasmitirles eso a ellas? Algo que a mi me ha funcionado y que a ellas posiblemente les funcione.

P $310^{\text {th }} \mathrm{G}$ T interview (48)

Teaching and learning exist in dialogical tension and recur upon each other (GUANGLU, 2012). Since they are nested, co-entangled systems, dialogicity and recursion occur at the level of the different components of each system, as well as among components of the distinct interacting systems, (teachers' and students') in the backdrop of context (the classroom, the school, the outside world) which constitute complex systems as well. Dialogicity and recursion challenge the deeply-rooted beliefs that learning is the direct result of teaching and the superior-inferior relation between teaching and learning to turn to another mode (GUANGLU, 2012, p. 91), to a dialogical mode in which teaching is learning and learning is teaching (GUANGLU, 2012, p. 96). Recursion happens within and across time frames, within individual learning systems and across them, not in binary opposition but in dialogical interaction.

In the following section, I turn to self-eco-organizing and emergence principles in the learning systems of both teacher's and learners' in this study.

\section{Self-eco-organization and emergence}

Morin (1994) highlights the role of context, or ecology, in the selforganizing dynamics of any system. He maintains that an organism is never really self-organizing, but rather, builds itself up out of an already existing environment, into the existing ecology, that is to say, systems are self-ecoorganizing (the way water organizes around a fallen leaf). I relate the self-ecoorganizing principle explicitly to the emergence principle. Larsen-Freeman and Cameron relate them too and they state that "self-organization leads to new 
phenomena $[\ldots]$ a process called 'emergence'". They go on to explain that "what emerges as a result $[. .$.$] is something different from before: a whole that$ is more than the sum of its parts and that cannot be explained reductively through the activity of the component parts" (2008b, p. 59). In Morin's terms, the emergence principle in organized realities (sets, systems) relates to the new qualities and characteristics or emergences that cannot be reduced to the initial characteristics of the parts (1994).

Students and teachers in these classes display self-eco-organization and emergence at different moments. I perceive these in their ability to take advantage of the existing opportunities in their surroundings to build up their unique reality as language users and/or language teachers or just as human beings; they use the available resources or opportunities and transform them (or not) into something that is their own, new or emergent self. To refer to this idea, van Lier (2000, 2004, and 2008) borrowed a term from ecology (GIBSON, 1986), and introduced it into our field: affordance. As Menezes (2011) elaborates "[...] emergence happens when one responds to opportunities for interaction, to demands and constraints, or to offerings and obstacles, reorganizing and adapting themselves to the changing conditions in a niche" $(2011$, p. 4). Selfeco-organization and emergence are illustrated below in the form of affordances that students and teachers respond to in and beyond the classroom.

In extract 8 , a student is talking about the activities the teacher proposes to enhance her learning. The student says the teacher gives them vocabulary and then she drills the pronunciation of that vocabulary. This learner and the group, in general, seem to find these drilling activities helpful. The student seems aware that repetition is important for her language learning. As a class, they respond to these activities, interacting, adapting and learning from them. The student in 8 seems to show an awareness of the importance of lexical and pronunciation input to later transform it into intake and output as suggested in the Input Hypothesis (KRASHEN, 1985). Activities that traditionally could be considered not communicative, like the vocabulary drilling one, are noticed and taken as opportunities for learning by this learner. Students selfeco-organize around existing possibilities and their learning process and development move forward as a result of those possibilities they take.

1. R: ¿Cómo explica bien?¿Qué hace ella para que tú aprendas?

2. S1: O sea, ella hace como un vocabulario. 


\section{3. $R$ : Ajá.}

4. S1: Y ella dice y nosotros pronunciamos como ella lo dice, entonces asi lo vamos aprendiendo a pronunciar y también a pronunciar para hacer oraciones.

In 9 , a learner from $10^{\text {th }}$ grade reports the affordances or possibilities she notices in class and which she takes and finds useful. She reports vocabulary drilling (a behaviorist activity) and looking up the meaning of words in the dictionary (an apparently cognitively oriented activity). She reports working in groups (a socio-culturally oriented activity) as the activity that helps her to understand the L2 the most.

(9)

R: De las cosas que haces en la clase, ¿Cuáles son las que sientes que más te ayudan a aprender, a progresar?

S3: Ehm. Los vocabularios, siempre, los vocabularios y cuando hacemos actividades que le buscamos el significado a alguna cosa y cuando hacemos actividad en grupo es cuando más entiendo, ya.

P8 $10^{\text {th }}$ G S Interview (270-271)

Affordances are opportunities, but also constraints (MENEZES, 2011). The learner in 10 reports difficulties, constraints in the process, but does not seem aware of what causes them, however, she reports using her peer as a resource, to compensate for her lack in comprehension. She self-organizes around her current conditions, difficulties and possibilities and acts upon them to keep her process in movement.

1. R: Aja, ¿cómo sabes que no entiendes, ¿qué sucede, cómo sabes tú eso? ¿Las explicaciones no las comprendes?, ¿qué es lo que te pasa?, cuando la profesora está hablando y habla y habla y dice, ¡tú qué?

2. S1: Yo no entiendo.

3. R: Quedas gringa, jajajaja!

4. S1: Entonces le tengo que preguntar a ella.

5. R: Ay, pero, entonces, ¿cuando le preguntas a ella entiendes? ¿Cómo?, ¿qué hace ella para que tú entiendas?

6. S1: Ella me traduce lo que dice la seño.

7. R: Te traduce, o sea que la traducción te sirve. ¿Y tú entiendes? 
Extract 11 is a part of the $6^{\text {th }}$ grade class where there is a presentation, practice, production (PPP) linear sequence. From turns 2 to 14, the teacher and the students create a text together. Students follow the teacher's text as she builds it and some contribute with their own ideas to complete it. Some students perceive the possibility to communicate, to interact and they take it; they see and take advantage of the affordance. Some students appropriate the possibility to communicate about something they know (their teacher's personality), with language they are learning, some others do not.

1. T. OK... Here in the photocopy you have an exercise, here you have to write your description... I am going to copy in the board... I am going to copy the exercise on the board.

I am (name, age, nationality)

My hair is (color and shape)

My eyes are (color)

I am (personality)

2. T. I am going to write an example. (She writes and she reads aloud).

3. I am Luisa. I am 35 years old. I am Colombian. My hair is long. My eyes are brown. I am intelligent...

4. S1. Fantastic.

5. T. FANTASTIC.

6. S2. Lovely.

7. T. Lovely. (The teacher writes what students suggest smiling at their suggestions).

The exchange continues in extract 12 and some other learners seize the opportunity provided by the teacher in this activity to use the language (turns 10 to 14). Most students in this context perceive language affordance as "speak it" (MENEZES, 2009, p. 9) and they take the opportunity they perceive to advance/forward their learning of the language.

8. This is my description... Now, you write your descriptions in the copy... OK? Yo me voy a llevar todas las fotocopias para revisarlo. (Teacher gives them some minutes to complete it. She monitors their work and then says)

9. T. Now two persons... two people are going to read it alone. I am going to listen to the descriptions.

10. S. I am Giselle. I am eleven years old I am Colombian. My... hair is long and blond. My eyes are brown. I am smart. 


\section{T. Another student?}

12. S. I am Paola... I am 11 years old. I am from Colombia. My hair is long and black.

13. T. Shirley and we finish.

14. S. I am Shirley. I am 11 years old. I am Colombia. I am young. I am happy.

15. T. Now we're going to put this photocopy aside... Now, we're going to work with the English book. Open your book on page number 25... These are some famous people. What's his name? (pointing to a picture)

16. S. He is Brad Pitt.

17. T. What's her name...? She's a model, she's from Medellin...

18. S. Natalia Paris.

19. T. Natalia Paris. We're going to listen ... listen to the description and we're going to write which person they are describing. ¿Qué vamos a hacer, Daniela?

20. S. Vamos a escuchar la descripción de las personas y vamos a decidir cuálpersona es. (Tape plays. The students next to me already did it... I ask her she says she did it at home).

P1 6G Class (871-900)

\section{Self-eco-organization and emergence in teacher's learning systems}

Teachers' learning systems also self-organize and show emergences of different kinds. The $10^{\text {th }}$ grade teacher when looking back at a class she taught (13) reviews her planning and design decisions, the aims for chosen activities and the evidence of learning or lack of it. There is interplay of cognitions instantiated in this narrative. One can notice her instructional cognition in the planning stage and in the design and assessment stages. One can have a glimpse of her interactive decision-making when she refers to the scaffolding she provided to help students succeed. She also shows her curricular-institutional cognition at play when referring to the alignment of the type of activities she selected and implemented considering the students' need to pass a standardized national exit exam. There are pre-existing conditions in the school context, in the context of students' current learning needs and language level; the teacher's instructional decisions flexibly adapt to the situation and self-organize around real time events that happen differently from what she had planned. At one level, the instructional cognition level, she self-organizes to adapt to current happenings from the class; at a different level, the curricular-institutional cognition level, she maintains her goal fixed. 
In a previous class I asked students to look the meaning of the new words we extracted from the unit. The intention of this is to have the first contact with the word by looking up their meaning in Spanish. I prepared a matching activity where they had to work in groups. They needed to match the definition with their corresponding words. It was hard for the students to do it alone. It required some scaffolding from the teachers to help them finish up the activity. It seemed students like the activity because I saw them very enthusiastic: yelling, laughing. Besides, all of them participated. I could notice that in some groups there were some participants that did not study all the words just half as they confessed when I asked them. This of course was a disadvantage for them when completing the activity. In general, they showed enthusiasm during the performance of the activity. This strategy of matching concepts with meaning is necessary that I do it in class because it is very similar to the way ICFES or PRUEBA SABER $11^{6}$ evaluate vocabulary in the second part of the exam.

P $410^{\text {th }}$ GT Journal (16)

As the narrative continues (14), the teacher starts deploying parts of her learning system. She notices aspects of her class; she connects her different cognitions and displays them to make sense of what happens in the class. She is drawing on her knowledge of students, on her instructional knowledge, she seems to be in a process of discussion of the theory she has read with what actually is happening in the concrete class experience. The process is dialogical, in a very recursive manner: she goes to her practice then back to her knowledge, she sees what works well and what doesn't, she thinks of what to do in the future. She puts her practice under close scrutiny and confronts it with theory, appropriating the theory and making it her own by assigning meaning to it with her own practice, to her own learners. She seems to be in a process of internalization of knowledge, of self-organization of her learning to accommodate the newness of her new emergent teaching self. There seems to be a process learning to teach by teaching.

However, if I have to teach this class again I think I would shorten the activity and write definition in context and not just the concept of the word.

\footnotetext{
${ }^{6}$ ICFES Exam or PRUEBA SABER 11 are National Standardized tests that students exiting high School should take. More information in <http://www.mineducacion. gov.co/1621/w3-article-244735.html>.
} 
Then, I continued checking the exercise students were to prepare at home: vocabulary exercise. It was more a checking exercises centered class. While teaching the class, I required oral answers to check if the answers were right. I noticed that most of the students did their exercises. I also noticed that these students do not require so much input to be motivated or interested in classes because this was not a very dynamic one. Understanding dynamic as an "active" action where students usually participate eagerly. What makes me assume that the input factors as intrinsic motivation is very strong. They are always in a good willing to learning. Now, taking this as a mirror of my teaching practice, I think I should have concentrated more on those weak students at the back, those that are a little bit shy. The class went according to what I planned: check the exercises, but I really should have dedicated more time to students interacting in a more meaningful way: Like planning an activity where they can describe their favorite television programs and talk about last episode of one of them. I just stuck to the exercise suggested by the book. I should have adapted one of the activities to their context.

P $410^{\text {th }}$ GT Journal (17-18)

Every teacher is unique in the ways she learns teaching and in the resources she uses to discuss the learning process. The $6^{\text {th }}$ grade teacher displays cognitions in her narrative as well, similar in many ways to the ones displayed by the $10^{\text {th }}$ grade teacher, but different and unique at the same time. In her narrative (15) she starts by referring to her practice. She starts with changes she is introducing in her teaching; changes that reflect her own awareness that her students need a shift to balance the development of skills. This reflects her knowledge of students and her instructional knowledge. She shows self-eco-organization and as a result there emerge new tasks to meet those changing needs: she moves from activities that develop oral skills to activities that develop reading skills. In retrospection, she expresses the dissonance she felt when students did not respond as expected to the new reading task. She reveals some of her instructional knowledge on which she based her planning decisions, familiarity of students with vocabulary, and also reveals a gap in her design of level-appropriate reading tasks for her learners. She closes this short narrative making reference to her choice of material assessing negatively the effectiveness of the choice. I see emergence of awareness of her learners, awareness of the impact of her instructional decisions on students' learning or lack of it, and the importance of material to support teaching and learning. I see various cognitions at play: knowledge of students, instructional knowledge which encompasses tasks and material design considerations. Her various kinds of knowledge flexibly organize to assess current practice and to set actions to adapt her teaching to the new understandings she is constructing about her practice and how it connects to students' learning. 
As I've been working on oral skills lately, I wanted to introduce a different kind of task, so I presented a short paragraph and students were ask some questions about it using there is, there are, articles an- $a$ and the verb to be.

At first I thought they were going to understand the paragraph very well because it had words or expressions they already knew but we had problems in comprehension even though it was a basic level paragraph.

I found it interesting to practice there is and there are too, but I think I should have brought a big poster, instead of that I used a photocopy and I didn't go as I expected.

P $26^{\text {th }}$ GT Journal (25-27)

Affordances do not only happen within the classroom, they happen outside the context of the classroom, in the outside world, a world in which learners (teacher and students) live and grow. Learners self-eco-organize around the opportunities they perceive in the outside world and their learning systems are infused in ways that we can only start to perceive.

Language possibilities or affordances are not the same for every learner (student or teacher). Based on their experience as learners, students, for example, share what has worked well for them and could help others learn, too. Students seem aware of that they need to act upon opportunities, to interact not only inside the class, but also outside. In extract 16, a learner reports engaging in activities such as listening to CDs in English and repeating vocabulary as a strategy to reinforce vocabulary learning. She also seems aware of the need to interact with others and reports using that possibility outside the classroom walls: speaking with a parent. The opportunities for learning that other students in $6^{\text {th }}$ grade mention (16 to 19) are realized beyond the classroom and include cognitively oriented (studying and reviewing, reading, listening to CDs) and socially oriented ones (asking others for help). It is interesting to notice that most of the strategies reported by these learners reflect a behaviorist theory of learning, drilling, repetition of pronunciation, writing sentences to master structures. What they do outside the classroom may somehow replicate their experience in classrooms, their own apprenticeship of observation. Students' learning systems self-eco-organize around existing conditions making the best of what is available and changing the way their learning trajectories develop. 
Escuchar CD sobre inglés, si no entiendes algo lo puedes repetir varias veces hasta que la palabra se te grabe en la mente, si yo por ejemplo, cuando estoy hablando con mi papá y mi papá me dice, ajá vamos a hablar inglés!

P 26 G S interview (210)

Mi recomendación sería, que se aprendan los verbos que son importantes, estudiar, leer libros, escuchar $C D$ de inglés, si la seño no explica bien, si no entiende bien, pregúntale a un familiar, de pronto el familiar también sepa y puede aprender más.

P 26 G S interview (214)

Yo leo los libros de inglés y me pongo a veces cuando no tengo nada que hacer, me pongo a leer o me pongo a hacer oraciones en inglés.

P 26 G S interview (91)

Yo leo los libros y traduzco a veces lo que dicen, entonces si no sé cómo decir una palabra, la busco en el diccionario y la escribo debajo de las letras.

P 26 G S interview (93)

Students in $10^{\text {th }}$ grade have had a wider experience as language learners and users. They seem aware of the benefits of the activities that they have lived in their learning process and make reference to practices that illustrate them. Extract 20 illustrates learner's awareness of the affordances beyond the classroom. This learner seems to have distinct conditions in the ecology of her learning context: she seems to have a feeling of affiliation with the L2, she reports having expanded her resources and possibilities outside the classroom with a variety of cultural artifacts, and reports she makes sense of the process by sharing in groups. It seems that she expands her learning process with others even if the others are in a similar language proficiency level. She notices the opportunities of talking in English and she takes them because for her, as for $6^{\text {th }}$ graders, speaking the language is learning the language. 
(20)

1. R: Te traduce, o sea que la traducción te sirve. ¿Y tú entiendes?

2. S2: Si, yo entiendo.

3. $R: Y$ ¿cómo entiendes?, ¿por qué entiendes?, ¿qué haces?, ¿qué es lo que te gusta hacer?

4. S2: A mísiempre me ha gustado el inglés.

5. R: Aja, y eso te ayuda, ¿Crees tú?

6. S2: Si, porque en la casa yo me guio con las películas, con la música, que me ayuda. Las palabras, me ayuda a entender a la seño cuando habla en inglés.

7. R: Entonces, cuando tu estas en la clase aquí la profesora propone actividades y dice vamos a hacer esto, aquello, de lo que ella propone, ¿qué es lo que sientes tu mas que te ayuda?

8. S2: Cuando hacemos actividades en grupo.

9. R: En grupo.

10. S2: Si, porque podemos hablar entre nosotras y aunque no sabemos mucho, con ella nos ponemos a hablar en inglés aunque no sepamos mucho, entonces me gusta cuando las actividades son en grupo. Yo siento que socializo bastante. Voy soltándome más con ellas.

11. R: Ese soltar es, ¿Quésignifica soltarme más?

12. S2: Hablo bastante, empiezo a hablar y me gusta, no sé, me gusta bastante hablar con la compañera, en inglés claro.

P 26 G S interview (222-239)

Affordances are around learners. It is up to the learners to perceive what is around them and to exercise their agency, their capacity to act [or not to act] upon the options they perceive $(\mathrm{GAO}, 2010) .10^{\text {th }}$ grade learners in extracts 21 and 22 mention various cultural productions (songs, movies) as important for the learning process. Some of them act by reading books and magazines, by listening to songs, watching movies. They notice some of the possibilities beyond the classroom and grab them to expand their possibilities as language users and as member of a larger language community.

Las actividades que yo realizo que influyen en mi aprendizaje es la música en inglés,...

P13 $10^{\text {th }}$ GS Journal L. (3) 
Desde la perspectiva como estudiante o alumna respecto a mis acciones o actividades que realizo diariamente busco mi motivación en el inglés a través de medios divertidos, como ejemplo aprendo canciones en inglés y busco sus respectivos significados, trato de ver peliculas y programas en la tv con el idioma en inglés buscando la forma de entenderlas ya que son programas llamativos y atractivos que motivan a verlos y entender el idioma.

P12 $10^{\text {th }}$ GS Journal J. (1-2)

Teachers' learning and students' learning are complex systems which are nested, co-entangled within the classroom, (another complex system) and beyond it (an even more complex context). Self-eco-organization and emergence characterize complex systems and they are indicative that the system is alive and functioning; the lack of self-eco-organization and emergence indicates that the system is dead or decayed.

In the following section, let's continue with illustrations of the holographic principle as perceived in the case.

\section{The Holographic Principle}

The holographic principle states that the part/whole distinction is present in every system in such a way that the part is in the whole, but the whole is, holographically, also in the part. Learning systems are not the exception and therefore show the holographic principle in action at different levels.

\section{Holographic principle in the teachers' learning system}

In one micro decision made by a teacher, one may see the whole of her cognition at play; the teacher's learning system composed by different cognitions and these cognitions are realized in the minute-to-minute decisions in the class: the part is in the whole and the whole is also in the part. In 23, a part of the $6^{\text {th }}$ grade class to illustrate the hologram I perceive. 


\begin{tabular}{|c|c|}
\hline $\begin{array}{l}\text { T. Nice, lovely, happy, great, fantastic, good, noisy, } \\
\text { boring, exciting, intelligent, outgoing, shy. } \\
\text { S. Nice, lovely, happy, great, fantastic, good, noisy, } \\
\text { boring, exciting, intelligent, outgoing, shy. }\end{array}$ & $\begin{array}{l}\text { Instructional knowledge: providing lexical input, } \\
\text { importance of drilling of vocabulary, choice of } \\
\text { words according to the needs of learners, drilling } \\
\text { gives them confidence. }\end{array}$ \\
\hline T. You are going to... Copy in your notebooks. & \multirow{7}{*}{$\begin{array}{l}\text { Knowledge of students: they need other words } \\
\text { different from the ones in the book. } \\
\text { Institutional knowledge: some students do not } \\
\text { have books. } \\
\text { Instructional knowledge: copying helps learners } \\
\text { remember words better, it keeps them quiet, it } \\
\text { helps them familiarize with the spelling of words. }\end{array}$} \\
\hline S. Seño, Seño. & \\
\hline \multirow{3}{*}{$\begin{array}{l}\text { T. OK, copy in your notebooks the new vocabulary. } \\
\text { OK, we have some different expressions in the } \\
\text { photocopy, extra vocabulary. We don't have these } \\
\text { expressions in your English book. For example, we have } \\
\text { here... nice, we have lovely, happy, great, fantastic, } \\
\text { good, noisy, boring, exciting, intelligent, }\end{array}$} & \\
\hline & \\
\hline & \\
\hline \multirow{2}{*}{\begin{tabular}{l|l} 
S. Teacher, ¿esto es una l? \\
T. Si.
\end{tabular}} & \\
\hline & \\
\hline \multirow{2}{*}{$\begin{array}{l}\text { T. Outgoing, shy, yes? The list we have here are } \\
\text { physical no... physical characteristics... and these } \\
\text { ones are characteristics of the personality... yes? For } \\
\text { example, Stephanie. Come here. Come here... we are } \\
\text { going to describe Stephanie. What are the physical } \\
\text { characteristics of Stephanie...? she is }\end{array}$} & $\begin{array}{l}\text { Instructional knowledge: listing words help them } \\
\text { remember better, organize learning process. }\end{array}$ \\
\hline & $\begin{array}{l}\text { Providing a context for the use of vocabulary, } \\
\text { makes learning more memorable, authentic. }\end{array}$ \\
\hline S. She is gorda... & \multirow{3}{*}{$\begin{array}{l}\text { Instructional knowledge: encourage use of L } 2 \text { to } \\
\text { say what they mean. }\end{array}$} \\
\hline T. Remember we have to use English. & \\
\hline S. She's beautiful. & \\
\hline T. She is beautiful, very good. & \multirow{2}{*}{$\begin{array}{l}\text { Instructional knowledge and knowledge of } \\
\text { students: providing positive assessment encourages } \\
\text { learners, provides a feeling of achievement. }\end{array}$} \\
\hline S. She is young. & \\
\hline $\begin{array}{l}\text { T. She is young, very good. She's is beautiful. These } \\
\text { are the physical characteristics, but which one are her } \\
\text { personal characteristics? Yes, she is young... These are } \\
\text { her physical characteristics, but which are her } \\
\text { personality characteristics? }\end{array}$ & $\begin{array}{l}\text { Instructional knowledge: knowledge of the language, } \\
\text { providing examples of language use in context, } \\
\text { authentic language and content. }\end{array}$ \\
\hline
\end{tabular}

P1 6G Class (596-609)

\section{Holographic principle in students' learning system}

From students' narratives I am able to perceive in holographic fashion the web of their learning system, their cognitions. Students' learning systems are complex as documented in studies undertaken from various research traditions and perspectives that have aimed to account for students' language learning (KUMARAVADIVELU, 2006). Every aspect has been studied individually in order to assess its role in L2 development. As suggested by Kumaravadivelu (2006) and in accordance with the complexity perspective 
guiding this study, every aspect detected in students' learning systems is an important part of the system, each playing a facilitating (or limiting) role in the development of the learner's L2 knowledge / ability (2006, p. 31).

I will illustrate the hologram of students' learning systems using narratives from $6^{\text {th }}$ grade learners. The factors which are holographically present in the learning systems of students from $6^{\text {th }}$ grade have been reported by several studies in the SLA literature ${ }^{7}$ and include factors associated with the individuals such as age and anxiety, factors related to negotiation of language, such as interaction and interpretation; factors related to strategic learning such as the use of learning or communication strategies; affective factors comprising attitudes and motivation; knowledge factors including knowledge of the language and knowledge about the language and the environmental factors related to the social and educational context where learners interact. I used 63 narratives from $6^{\text {th }}$ graders for this analysis (but will illustrate with a short selection, though). Many narratives can relate to more than one factor of the learning system, and the separation is mainly done for clarity purposes. This overlapping per se says a lot about the interconnectedness and wholeness of the system.

Out of the 63 narratives, 15 make reference to negotiation factors. Negotiation refers to ways in which learners explore meaning in the L2 through interaction with other participants in communicative events, and in doing so they use and refine their linguistic and pragmatic knowledge/ability (KUMARAVADIVELU, 2006, p. 34).

In extract 24 the learner seems to refer to the role of the teacher as the most competent other with whom to engage in interaction in the class, a more competent other that provides good (my emphasis) input because she knows more. The learner in 25 refers more explicitly to her role in the communicative event and mentions that they need to respond correctly, to produce output in the L2; she seems to perceive it as an opportunity to refine her L2 knowledge. In 26, the learner may be referring to interaction in L2 and in L1 for the explanation she is referring to. As can be seen from these extracts interaction, negotiation and interpretation are part of these students' learning systems.

\footnotetext{
${ }^{7}$ See Kumaravadivelu, 2006 for a summary.
} 
.... [o] sea yo he aprendido bastante, yo he aprendido bastante porque la seño sabe bastante, nos explica bien, habla.

Cuando ella pregunta en clase que hay que decirle por ejemplo, ella pregunta algo y nosotras tenemos que responderle en inglés correctamente.

Si estudio sola, yo puedo ir traduciendo el libro y eso y si estudio en pareja, yo le puedo explicar a mi pareja y mi pareja me explica a mi.

Twenty-four narratives out of the 63 make reference to tactical factors, that is, learners' awareness of, and their ability to use, appropriate tactics or techniques for effective learning of the L2 and efficient use of the limited repertoire developed so far (KUMARAVADIVELU, 2006, p. 36), in other words, their learning and communication strategies. I would like to highlight the numbers here as they seem to suggest that the tactical factors make up an important component of their learning system. In extract 27 , the student refers to a variety of tactics: the teacher as a resource, studying and reviewing at home. Something worth noticing as well is the shared responsibility of learning that she is suggesting, her agency. In extract 28 the student highlights what to do to learn more, she mentions effortful study as particularly important She may be repeating what the teacher has told her, whatever the case may be, this may be a very important component of her learning system as it has been reported that learners that hold these beliefs are more likely to have sustained and dynamic learning trajectories (COLVIN, 2008; DWECK, 2007).

Yo creo que sí, porque o sea tenemos nueva profesora, la profesora sabe bien hablar inglés, nos enseña bien, nosotras también estudiamos en la casa, entonces cuando venimos al colegio la seño nos explica pero de todos modos ya nosotras sabemos.

Para aprender inglés ellas tienen que prepararse más, esforzarse más y estudiar más las cosas que ellas aun no han podido comprender y dialogar con su profesora de inglés para asi ellas aprender más sobre las cosas que ellas aun no pueden comprender. 
Sixth grade students' repertoire includes reviewing at home and engaging in cognitively-oriented activities, practicing/interacting with the teacher and other socially-oriented activities such as engaging with competent others in interaction (29). In 30, one learner seems to perceive their tactical knowledge in reference to advantages of different interaction patterns (interaction with oneself, with a peer-more competent or not -, with the group). Once more, their awareness of their own responsibility for learning is outstanding in their learning system, especially noticeable given their age (11-12).

Mi papá sí me enseña y mi hermana, entonces mi papá a veces me dice, vamos a hablar inglés! Y nos ponemos a hablar inglés y la palabra que yo no entiendo, él enseguida me pone a buscarla en el diccionario y a leer libros sobre eso.

Yo creo que en los tres, porque en los tres uno puede aprender más, en grupo estamos aprendiendo porque si yo no sé algo el grupo me lo explica.

Thirteen narratives out of the 63 refer to affective factors or learners' disposition to learn which encompasses attitudes and motivation as the variables from this factor most frequently discussed in literature (KUMARAVADIVELU, 2003, p. 38) and confirming this as well in the data. In all narratives, I perceive their positive attitude and motivation towards the language providing positive feedback to their learning systems as these variables seem to amplify the movement and development of the system. Responding positively to pair and whole-class activities (31), showing such an awareness of the usefulness of what they are learning and finding imagined applications for it (32), enjoying by what could be perceived as not particularly attractive activities by other learners indicates to me their enhanced apperception and disposition for learning.

[C]uando ella nos da unas fotocopias y ahi unas preguntas de a veces de los deportes que nos gustan, tenemos que... una pregunta y otra responde. Entonces nos pone en frente de toda la clase y nosotras lo tenemos que decir.

Para que cuando nosotros vayamos a otros lugares ya tenemos la práctica, por ejemplo si estamos en Cali, ya sabemos nosotras sabemos que la ropa es más abrigada que acá. 
Ten narratives make reference to either language knowledge or to metalanguage knowledge of their L2 and their L1 since both languages play a crucial role in L2 development (KUMARAVADIVELU, 2006, p. 41). They show this knowledge implicitly in many of the narratives where they mention the importance of engaging in sentence construction, in vocabulary learning, and in language practice activities that will contribute to their language development. In 33 and 34 they reveal part of their metalanguage knowledge.

Yo, lo que no entiendo muy bien es el presente progresivo.

Que aún no lo entiendo bien como se debe usar.

Necesito saber por ejemplo, cómo se forman las oraciones negativas y las preguntas.

Two narratives make explicit reference to environmental factors or the milieu in which language learning and teaching take place (KUMARAVADIVELU, 2006, p. 42). As can be deduced from their narratives, most of their language learning activities (reviewing, practicing) happen outside the classroom. This is interesting since it opposes common perceptions that students rely only on classroom interaction for their L2 learning. Students in 35 refer to "workshop activities" designed by the teacher to support their learning; they say they are completed in class, most of them at least. Extract 36 refers to the fact of having had English classes as a normal component of their curriculum. This shows us a snapshot of the institutional life and curricular decisions: English plays a role, it has been chosen to be part of the curriculum of this school, or of any other in which these learners have received their primary education.

En la clase.

Pero la mayoría son en la clase.

Yo desde que empecé en mi colegio siempre he dado inglés.

It is interesting that students' narratives do not make reference to one of the factors reported in the literature: the individual factors. Variables within the individual factors include age and anxiety, empathy, extroversion, introversion and risk-taking. The absence of related data in this case may 
suggest, first, that the outside interest of researchers in documenting these factors does not necessarily reflect learners' awareness of the impact this may or may not have in their specific learning, local learning process, at least not at this age. Secondly, that opposed to other factors that seem to emerge naturally out of their narratives, exploring this factor may require a more direct approach in order to elicit their views or just observe the variables in action.

In this section, I have attempted to highlight the holographic principle by disaggregating the dialogically intertwined factors or components that make up students' learning systems as reflected in their accounts. The resulting holograms show a glimpse of students' learning systems; however, they do not match exactly the research-oriented hologram projected in the literature. The map of students' learning systems projected by the literature serves its purpose in providing a reference, an abstraction of the wholeness, but the map can never replace the terrain: the locally-bonded reality of these students' learning systems. It is my suggestion that the micro-cases represented by the particular groups of learners are a hologram of the components of learners' learning systems as discussed in studies in the field. And as holograms they show the whole of students' learning systems in the micro-ecology of their particular classrooms. They are representing the global in the local.

\section{The Fuzziness Principle}

The fuzziness principle, even if not proposed by Morin directly as one, ${ }^{8}$ is considered by some authors as "an underlying principle of complexity" (GÓMEZ; JIMÉNEZ, 2002, p. 118, my translation). Fuzziness has to do with uncertainty, with ambiguity and multivalence. This principle allows the mind to reason with uncertain and indescribable statements and concepts (MORIN, 1988). This principle "opposes classical dichotomies such as manwoman, to be-not to be" (GÓMEZ; JIMÉNEZ, 200, p. 118, my translation). And as I like to say it allows us to handle the fact that in between black and white there is a wide variety of greys.

It allows us to understand that learning happens in life and that life is complex and problematic and so is learning as it is at the core of life. Understanding learning and teaching as dialogical, recursive, self-organizing and emergent as life itself requires a frame of mind able to handle this

8 "Si bien no se propone de manera directa un principio tal, creemos que es un principio activo del pensamiento complejo y, de una forma u otra, está presente en él”. 
multivalence. Understanding learning the foreign language, learning teaching (and any learning) as part of a grander learning system requires that we part from dualism and embrace wholeness. Understanding that simplicity is embedded in complexity and a crucial part of our learning is finding simplicity in complexity (RUBIO, 1992) as a way of handling the otherwise insurmountable complexity of life. I think that this is, in part, what the fuzziness principle helps us accomplish.

Data from the study is displayed to the researcher and the first movement into learning is finding the simplicity, the linearity within. In this case, I have confronted data with pre-existing frameworks arising from literature; I used abstractions of the reality from which the data emerge as a map to help me make sense of the uncharted territory. Now, I will attempt to highlight the ambiguity and multivalence inherent in those abstractions. The first aspect to highlight is the paradox of separating the principles of complexity which are by nature inseparable. It has been evident for me when looking at the data from the perspective of one principle to find the other ones nested within.

An aspect, in which I would like to illustrate the fuzziness principle in action, is the way teachers live theory and practice as one whole reality. ${ }^{9}$ The distinction made in the literature and by SLA researchers of the two activities merge in the reality of the classroom, and will be made evident as teachers and students live the classroom and show how the two activities are inherently connected so that each is necessarily rooted in the other. In other words, I will try to illustrate how fuzzy the dichotomy becomes when looked at through teachers' narratives and from extracts of classroom interaction where theory and practice are instantiated dialogically.

Below, the $6^{\text {th }}$ grade teacher mentions her evaluation of the book, and how she sees it as a resource to enhance autonomy. Her instructional-practical decisions about how to use the book and set up homework seem to show underlying theories about materials evaluation, the role of homework in encouraging student's autonomy, as well as error correction. One may see the theoretical underpinnings so totally integrated into her narrative and her classroom actions that it is difficult to tell them apart.

\footnotetext{
9 See Kincheloe, 1993; Kumaravadivelu, 2003, 2006; for detailed discussions on the integrative nature of theory and practice.
} 
Yo he tratado de que ellas hagan trabajos en casa que vayan desarrollando las unidades del libro, el libro de pronto yo no me siento muy cómoda con él pero si es una herramienta si yo lo veo desde el punto en que sirve para un trabajo individual y para un trabajo me imagino by themselves...

Más autónomo, que ellas trabajen solitas y que se den cuenta que es lo que están fallando, aunque nosotros dedicamos un tiempo para revisarlo en clase y corregir los errores y alli ellas se van dado cuenta de los errores que cometen, pues de pronto hacerlo más seguido hubiese sido muy importante para ellas, en el sentido de que hubieran caido en cuenta de susfallas.

P 1 6GT Interview (35-37)

I now turn to another aspect where I feel we need to move beyond our rooted Newtonian division of reality: teachers' and students' learning. In our constant quest for certainty characteristic of our western inherited view of science, we have invented learning (FRANSELLA; THOMAS, 1988) as we have invented teaching (DAVIS, 2004; JÖRG, 2009). Numerous contributions have been made to our current understanding of learning and teaching from this dichotomic perspective, but we may be imprisoned by it. We need a shift in mindset that allows us to think learning (and teaching) as complex systems in their irreducible, non-reified nature. We need this mindset so we can move from "identifying them, not just better understanding what makes them go, but [to make] more deliberate efforts to trigger them into being, to support their development, and to sustain their existence" (DAVIS; SUMARA, 2012, p. 31). So, as I would like to suggest, under our dichotomized perspective of reality we have separated unities into their parts: separated learning from teaching, separated students' and teachers' learning. Under a complexity perspective the division becomes less clear-cut, a bit more blurred and fuzzy because at the end of the day learning is learning.

In the figure below, I have borrowed the visual metaphor used by Davis and Sumara (2012, p. 31) to represent graphically how I expect learning to be understood, learning as a networked system. I think the complexity of learning, in particular, and the complexity of the educational endeavor, in general, could benefit a lot from this perspective as suggested by Davis and Sumara (2012). 


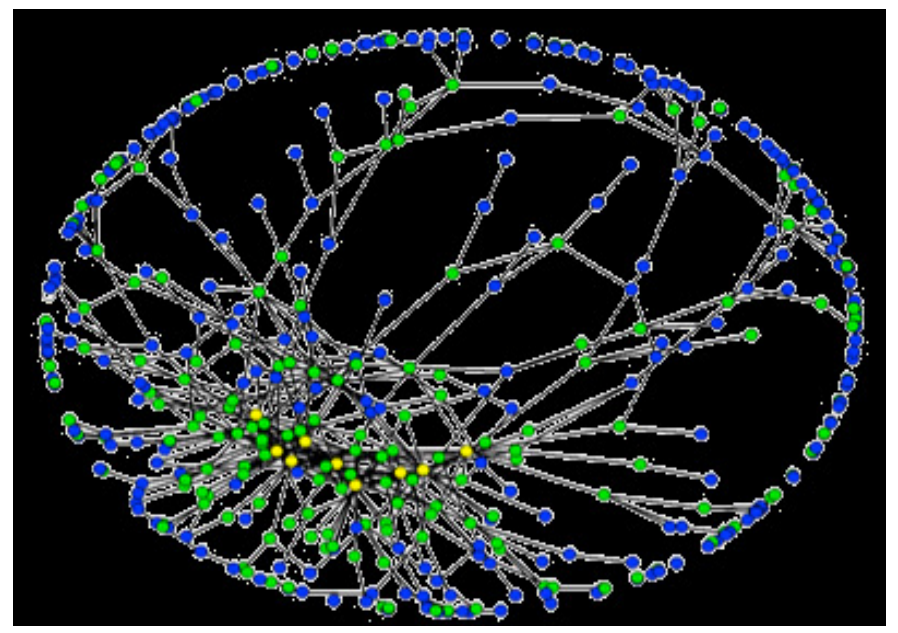

FIGURE 1 - "Learning as a networked system”

Classical dichotomies may prevent us from seeing the underlying commonalities, the entanglement of apparently disconnected systems. I have tried to illustrate how fuzziness, an essential underlying principle of complexity could allow us to make connections and see macro patterns in complex systems such as learning and teaching.

\section{An opening}

Caminante, son tus huellas

el camino y nada más;

Caminante, no hay camino, se hace camino al andar.

$\mathrm{Al}$ andar se hace el camino, y al volver la vista atrás se ve la senda que nunca se ha de volver a pisar. Caminante no hay camino sino estelas en la mar.

Antonio Machado (1912)

Machado, a complexivist par excellence, illustrates with his words the feeling of opening I would like to transmit at the end of this article.

In this report, I have attempted to illustrate the complexity of learning by analyzing how learning is instantiated and how learning instantiates complexity. I have used narratives from the persons and selections of their 
interaction in the classroom to show the principles in action. I have broken the wholeness of teaching and learning into components and then tried to put the pieces back again, to reconstruct what has never been separated. I hope to have honored the complexity of the phenomena which are the focus of this study: students' and teachers' learning in their non-linear, emergent, selforganizing, recursive, holographic and fuzzy nature.

I have attempted to share how a complexity perspective on understanding learning encompasses an understanding that learning is not a fixed system, that it emerges and self-eco-organizes around existing resources and even around imagined or past ones. I have attempted to show how everything is connected from the micro level to the macro level. I have tried to challenge some dichotomic rooted beliefs about learning.

Dialogicity, recursion, self-eco-organization and emergence challenge the deeply-rooted beliefs that learning is the direct result of teaching and the superior-inferior relation between teaching and learning in order to turn to another mindset (GUANGLU, 2012, p. 91), to a dialogical mindset in which teaching is learning and learning is teaching (GUANGLU, 2012, p. 96). Dialogicity, recursion, self-eco-organization and emergence happen within and across time frames, within individual learning systems and across them, not in binary opposition but in dialogical interaction.

I have illustrated the nested instantiation of activities originating from learning theories commonly perceived as opposing (behaviorist, cognitivist, and interactionist) occurring in a lesson, and/or a series of lessons, and co-existing dialogically and recursively. Dialogicity, recursion self-eco-organization and emergence, in these cases, are not only displayed in real time, synchronically, but also asynchronically. It was interesting to see how teachers, for instance, engaged in dialogical reflection with reality as perceived in retrospection. Teachers were able to set recursive actions based on their reflection on past practical experience from the class. Teachers also drew on experiences both from their more distant past as learners and from the more recent one as language users in the role of test takers (for example), as a reference for what they would like their current teaching to be. Teachers even base some of their instructional decisions, what to teach, and how to teach it, on those experiences.

Teachers deploy parts of their learning systems in different ways dialogically and recursively, in teachers' minute-to-minute classroom interaction, as well as in their retrospection. They display instructional cognitions, for example, in the planning stage of a lesson as well as in the design and assessment 
stages; in their interactive decision-making when they scaffold students to help them succeed; they display curricular-institutional cognition when they align the type of activities they select and implement to the students' present and future needs. They notice aspects of the class; they connect their different cognitions to make sense of what happens in the class. They draw on their knowledge of students, on their instructional knowledge, they confront the theory they read with what actually happens in the concrete class experience. They seem to go to their practice then back to their knowledge, they see what works well and what doesn't, and think of what to do in the future. They put their practice under close scrutiny and confront it with theory, appropriating the theory and making it their own by assigning meaning to it with their own practice, to their own learners. Self-eco-organization and emergence are displayed in variegated forms, for example, in instances in which teachers' instructional decisions flexibly adapt to the situation and self-organize around real time events that happen differently from what they had planned: teachers' various kinds of knowledge flexibly organize to assess current practice and to set actions to adapt teaching to the new understandings they are constructing about their practice and how it connects to students' learning. They seem to be in a process of internalization of knowledge, of self-organization of their learning to accommodate the newness of their new emergent teaching self. They seem to be learning to teach by teaching and by learning and this is how pre-determined concepts such as learning and teaching become fuzzy and difficult to disconnect in the reality of these cases.

I have highlighted how learning and learning-generating opportunities do not only happen within the classroom, they happen outside the context of the classroom, in the outside world, a world in which learners live and grow. Learners self-eco-organize around the opportunities they perceive in the outside world and their learning systems are dynamized in the process. Learners' learning systems self-eco-organize around existing conditions making the best of what is available and changing the way their learning trajectories develop.

Sixth graders, as illustrated above, see learning opportunities in behaviorist oriented activities: pronunciation drilling, sentence-writing drilling to master structures. Tenth graders have an expanded repertoire of possibilities, they also perceive and rely on cognitive oriented and socially oriented possibilities and use other cultural artifacts as mediation in their learning. Some show a feeling of affiliation with the language which feedbacks positively on their relationship with learning the language. What they perceive as learning opportunities inside and outside the classroom may be expanded and 
constrained somehow by their experience in classrooms, their own apprenticeship of observation. It is interesting how students perceive learning opportunities as displayed outside classroom proving wrong common perceptions that students rely only on classroom interaction for their L2 learning. As agentic learners, they adapt their learning process to what works best for them, to what they like, therefore creating better conditions for the advancement of their own learning.

The analyses presented in this article have attempted to reveal underlying commonalities, the entanglement of apparently disconnected systems, the connections, the macro patterns in complex systems such as learning and teaching. I think that classical dichotomies prevailing in research into learning: EFL learning and teachers' learning, are limiting the conceptual tools that we could use to see the systems in their openness, their nonlinearity, the constant flux and dynamism in their local context. Complexity epistemology is much more resonant with the complex nature of students' and teachers' learning systems. I hope I have illustrated that.

\section{References}

BRAINE, G. Nonnative speaker English teachers: Research, pedagogy, and professional growth. New York; London: Routledge, 2010. 112 p.

CHRISTIE, F. Classroom discourse analysis: A Functional perspective. London; New York: Continuum, 2002. 208 p.

COLVIN, G. Talent Is Overrated: What Really Separates World-Class Performers From Everybody Else. New York: Portfolio, 2008.

COUNCIL OF EUROPE. Common European framework of reference for languages, Cambridge: Cambridge University Press, 2001. 260 p.

DAVIS, B. Inventions of Teaching: A Genealogy. Mahwah: Lawrence Erlbaum Ass, 2004. 257 p.

DAVIS, B.; SUMARA, D. Fitting teacher education in/to/for an increasingly complex world. Complicity: An International Journal of Complexity and Education. v. 9, n. 1, p. 30-40, 2012.

DENZIN, N. K.; LINCOLN, Y.S. (Ed.). Collecting and interpreting qualitative materials. Thousand Oaks, CA: Sage Publications, 2008. 702 p.

DEVEREUX, G. From anxiety to method in the Behavioral Sciences. The Hague: Mouton, 1967. 
DWECK, C. Mindset: the new psychology of success. New York: Ballantine, 2007. FASSE, B.; KOLODNER, J. Evaluating Classroom Practices Using Qualitative Research Methods: Defining and Refining the Process. In: FOURTH INTERNATIONAL CONFERENCE OF THE LEARNING SCIENCES, 4. Proceedings. Eds. B. Fishman and S. O'Connor-Divelbiss. Mahwah, NJ: Erlbaum. 2000. p. 193-198.

FERYOK, A. Language teacher cognitions: Complex dynamic systems? System, v. 38, p. 272-279, 2010.

FRANSELLA, F.; THOMAS, L. Experimenting with personal construct psychology. London: Routledge and Kegan-Paul, 1988.

FROST, R. Mountain Interval. New York: Henry Holt and Company, 19201999; from. Available at: <www.bartleby.com/119>. Retrieved April 142012. GAO, X. Strategic language learning: the Roles of agency and context. Bristol: Multilingual Matters, 2010.

GIBSON, J. J. The Ecological approach to visual perception. Hillsdale, New Jersey: Lawrence Erlbaum, 1986.

GÓMEZ, R.; JIMÉNEZ, J. De los principios del pensamiento complejo. In: VELILlA, M. (Comp.) Manual de iniciación pedagógica al Pensamiento complejo. Corporación para el desarrollo, COMPLEXUS. ICFES, UNESCO, 2002.

GUANGLU, Z. On the recursion between teaching and learning. Complicity: An International Journal of Complexity and Education, v. 9, n. 1, p. 90-97, 2012. JOHNSON, K. Second language teacher education: A Sociocultural perspective. New York; Oxon: Routledge, 2009.

JÖRG, T. Thinking in complexity about learning and education: A programmatic view. Complicity: An International Journal of Complexity and Education, v. 6, n. 1, p. 1-22, 2009.

KINCHELOE J. L. Toward a critical politics of teacher thinking: Mapping the postmodern. South Hadley, MA: Bergin \& Garvey Publishers, Inc, 1993.

KRASHEN, S. D. The input hypothesis: issues and implications. London; New York: Longman, 1985.

KUMARAVADIVELU, B. Beyond methods: Macrostrategies for Language Teaching. New Haven; London: Yale University Press, 2003.

KUMARAVADIVELU, B. Understanding language teaching: From method to postmethod. Mahwah; New Jersey: Lawrence Erlbaum Associates, Inc., Publishers, 2006.

LARSEN-FREEMAN, D.; CAMERON, L. Complex systems and applied linguistics. Oxford: Oxford University Press, 2008b. 
LARSEN-FREEMAN, D.; CAMERON, L. Research methodology on language development from a complex systems perspective. Modern Language Journal, v. 92, p. 200-213, 2008a.

LOCKE, L., SPIRDUSO, W.; SILVERMAN, S. Proposals that work: A guide for planning dissertations and grant proposals. 4. ed. Thousand Oaks, CA: Sage, 2000. LORTIE, D. Schoolteacher: A Sociological Study. 2. ed. Chicago: University of Chicago Press, 1975.

MACHADO, A. Proverbios y cantares (XXIX): En Campos de Castilla, 1912-2012. Available at: <http://www.rinconcastellano.com/sigloxx/amachado.html $>$. Retrieved January 28, 2013.

MARKEE, N. Zones of interactional transition in ESL classes. The Modern Language Journal, v. 88, p. 583-596, 2004.

MARSHALL, C.; ROSSMAN, G. Designing qualitative research. Thousand Oaks, California: Sage, 2006.

MENEZES, V. Affordances beyond the classroom. In: BENSON, P.; REINDERS, $\mathrm{H}$. (Eds.). Beyond the language classroom: The theory and practice of informal language learning and teaching. Basingstoke: Palgrave Macmillan, 2011. p. 59-71. Available at: <http://www.veramenezes.com/publicacoes.html>. Retrieved April 14 2012.

MENEZES, V. Second language acquisition: from main theories to complexity (reelaboração do trabalho apresentado no congresso da AILA 2008), 2009. Available at: $<$ http://www.veramenezes.com/publicacoes.html>. Retrieved April 14, 2012.

MORIN, E. Method: Toward a study of humankind (v. 1: the Nature of Nature). New York: Peter Lang, 1977/1992.

MORIN, E. El conocimiento del conocimiento. Madrid: Cátedra, 1988.

MORIN, E.; J.-L. LE MOIGNE. L'intelligence de la complexité. Paris: L' Harmattan, 1999.

MORIN, E. Introducción al pensamiento complejo. Barcelona, España: Gedisa, 1994.

MUHR, T.; FRIESE, S. A user's guide to ATLAS.ti 5.0. 2. ed. Berlin: Scientific Software Development, 2004.

RUBIO, J. Interpretar la comunicación. Bogotá: Ed. Significantes de Papel, 1992. SWALES, J. M. Genre analysis: English in academic and research settings. Cambridge: Cambridge University Press, 1990. 
VAN LIER, L. Ecological-semiotic perspectives on educational linguistics. In: B. SPOLSKY.; F. M. HULT (Eds.). The Handbook of Educational Linguistics. Malden, MA: Blackwell, 2008, p. 596-605.

VAN LIER, L. From input to affordance: Social-interactive learning from an ecological perspective. In: J. LANTOLF (Ed.). Sociocultural Theory and Second Language Learning. Oxford: Oxford University Press, 2000. p. 245-259.

VAN LIER, L. The ecology and semiotics of language learning: a sociocultural perspective. Boston: Kluwer Academic, 2004.

YIN, R. Case study research: Design and methods. 4. ed. Thousand Oaks, CA: SAGE Publications, 2003.

Recebido em 31/01/2013. Aprovado em 04/04/2013. 